\title{
Do euglossine males (Apidae, Euglossini) leave tropical rainforest to collect fragrances in sugarcane monocultures?
}

\author{
Paulo Milet-Pinheiro ${ }^{1} \&$ Clemens Schlindwein ${ }^{2}$ \\ 1 Programa de Pós-Graduação em Biologia Vegetal, Universidade Federal de Pernambuco. Avenida Professor Moraes Rego, \\ 50670-901 Recife, Pernambuco, Brasil. E-mail: miletpinheiro@hotmail.com \\ 2 Departamento de Botânica, Universidade Federal de Pernambuco. Avenida Professor Moraes Rego, 50670-901 Recife, \\ Pernambuco, Brasil. E-mail: schlindw@ufpe.br
}

\begin{abstract}
Euglossine bees are known to be long-distance pollinators in tropical rainforests. But there is controversy concerning to the flight ranges of these bees between forest fragments. In an isolated fragment of Atlantic Rainforest in Pernambuco, NE Brazil, surrounded by sugarcane monocultures, it was examined if euglossine males leave closed rainforest to collect fragrances. In a straight-line transect leading from forest into a sugarcane plantation, euglossine males were simultaneously captured by scent baits at seven distinct points: inside the forest, forest edge, outside the forest in the sugarcane fields at distances of $10 \mathrm{~m}, 50 \mathrm{~m}, 100 \mathrm{~m}, 250 \mathrm{~m}$ and $500 \mathrm{~m}$ from the forest edge. A total of 945 euglossine bees of 16 species were recorded. The results demonstrate different relations of the Euglossini species to the closed forest. Males of 11 species did not leave the forest. Such species, together with the plants they are linked to, seem to be the most threatened by habitat fragmentation. Only bees of five species were found at the scent baits in the sugarcane fields. Already the $10 \mathrm{~m}$ sampling point outside the forest showed a drastic reduction in species richness, indicating that the forest edge functions as a barrier for most euglossine species.

KEY WORDS. Atlantic Rainforest, habitat fragmentation, Northeast Brazil, orchid bees, scent baits.
\end{abstract}

RESUMO. Machos de Euglossini deixam a floresta tropical para coletar fragrâncias em uma monocultura de cana-de-açúcar? Abelhas Euglossini são conhecidas por serem polinizadores de longas distâncias em florestas tropicais. No entanto, existem controvérsias sobre o raio de vôo dessas abelhas entre fragmentos florestais. Em um fragmento isolado de Mata Atlântica, cercado por monoculturas de cana-de-açúcar, em Pernambuco, Nordeste brasileiro, foi examinado se os machos de Euglossini deixam a mata para coletar fragrâncias. Machos de Euglossini foram capturados simultaneamente por iscas odoríferas ao longo de um transecto em sete pontos: interior da mata, borda da mata e no canavial, a distâncias de 10 m, 50 m, 100 m, $250 \mathrm{~m}$ e 500 m da borda. Foram registrados 945 indivíduos de Euglossini pertencentes a 16 espécies. Os resultados mostram diferentes relações das espécies de Euglossini com a floresta fechada. Machos de 11 espécies não saíram da mata. Essas espécies, juntamente com suas plantas relacionadas, parecem ser as mais ameaçadas pela fragmentação do habitat. Apenas abelhas de cinco espécies foram encontradas em iscas odoríferas no canavial. Além do mais, o ponto de amostragem de $10 \mathrm{~m}$ fora da mata mostrou uma acentuada redução na riqueza de espécies, indicando que a borda da mata é uma barreira para a maioria das espécies de Euglossini.

PALAVRAS CHAVES. Fragmentação de habitat, iscas odoríferas, Mata Atlântica, Nordeste brasileiro.

The Euglossini are neotropical bees, most of which are found in hot and humid equatorial regions (Moure 1967). As effective pollinators they display relationships with numerous associated plant species, including buzz-pollination flowers, resin flowers, perfume flowers and long-tubed nectar flowers, playing thus, a key role in maintaining diversity in tropical rainforests (Dressler 1982, BuCHMANN 1983, ACKerman 1985, Roubik 1989, Schlindwein 2000, Cameron 2004).
One of the outstanding features of euglossine bees is that males collect floral perfumes (volatile lipids) produced in osmophores of more than 700 species of Orchidaceae and other plant families (Vogel 1962, 1966, 1999, Dressler 1982, CAMEroN 2004).

Several components of these fragrances that make part of the flowers' bouquet may be used as chemically pure substances to attract euglossine males. This method has been re- 
peatedly used to survey Euglossini and to perform studies about abundance, seasonality and population dynamics in various neotropical forest formations (see for example Roubiк \& Ackerman 1987, Wittmann et al. 1988, Bezerra \& Martins 2001, RoubiK 2001, 2004, Neves \& Viana 2003).

The Brazilian Atlantic Rainforest currently covers less than $8 \%$ of its original area, encompassing around $91,000 \mathrm{~km}^{2}$. In Pernambuco and other states of NE-Brazil, only small fragments of Atlantic Forest, that are usually surrounded by sugarcane plantations, are currently remaining (RANTA et al. 1998). Such monocultures do not offer any flower resource or nesting sites required by the bees, therefore isolating the fragments of forest. To guarantee the reproductive success of plants that depend on pollination by euglossine males like those of Catasetum Rich. ex Kunth., 1932, Stanhopea Frost ex Hook., 1829 and Gongora Ruiz \& Pavón, 1794 species, flights of these males among forest fragments are necessary (MARTINI et al. 2003).

Euglossine bees are known to be long-distance pollinators in closed rainforests where flight ranges of more than 20 $\mathrm{km}$ have been demonstrated (JANZEN 1971, KROODSMA 1975, ACKERMAN et al. 1982). On the other hand, there is controversial information concerning to the flight ranges of these bees between forest fragments and the relationships between fragment size and abundance and species richness of Euglossini (Powell \& Powell 1987, Becker et al. 1991, Franceschinelli et al. 2003, TonHAsca et al. 2003). To get information on the flight behavior of euglossine males and on the relationship of the different euglossine species to forest habitats we tested attraction to scent baits in the extreme landscape of forest fragments inside a matrix of sugarcane monoculture in Pernambuco and asked the following questions: 1) Do Euglossini males leave the forest to collect fragrances outside the forest?, 2) Are there differences among the euglossine species in relation to their dependence on forest habitats?, and 3) To what distance do the male bees advance into sugarcane fields in search of fragrances?

\section{MATERIAL AND METHODS}

\section{Study site}

The field study was carried out in the forest fragment "Mata de Bujary" (476 ha, altitude 95 m MSL, 07³6.403's, $\left.34^{\circ} 58.925^{\prime} \mathrm{W}\right)$, municipality of Goiana, an area in the "Zona da Mata" region of Pernambuco, where vast sugarcane fields prevail and surround fragments of native Atlantic Rainforest. The studied forest remnant was separated from the next Atlantic Rainforest fragment by a distance of at least two kilometers (Fig. 1).

\section{Sampling of Euglossini}

The following seven sampling points were established along a transect: a) within the forest fragment, b) at the forest edge, c) within the sugarcane plantation $10 \mathrm{~m}$ distant from the forest edge, d) $50 \mathrm{~m}$ distant, e) $100 \mathrm{~m}$ distant, f) $250 \mathrm{~m}$ distant, and g) $500 \mathrm{~m}$ distant.

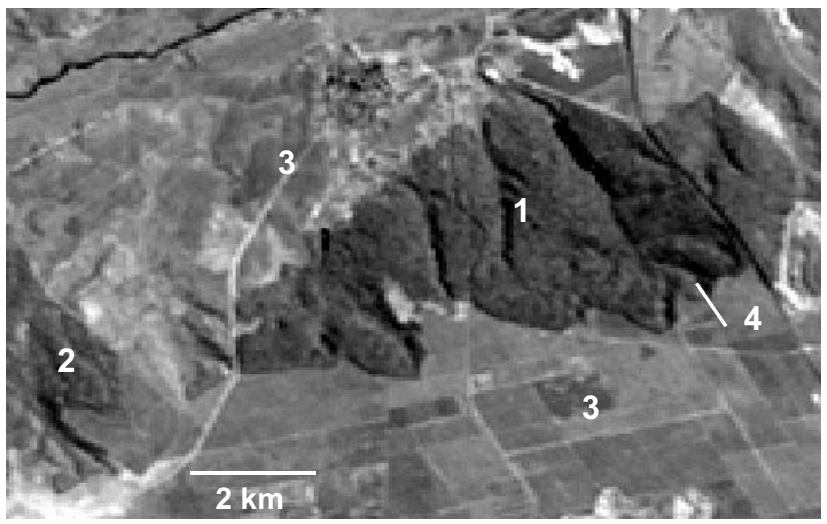

Figure 1. Satellite image with the rainforest fragment "Mata de Bujary" (1) surrounded by sugarcane monocultures (3). The smallest distance to the neighboring fragment is $2 \mathrm{~km}$ (2). Transect with the sampling points (4).

Five samples were collected on the following days: 25/XI/ 2002, 09/XII/2002, 17/III/2003, 16/IV/2003 and 01/VIII/2003. The euglossine males were attracted by scent baits (pieces of filter paper containing droplets of fragrance solution) between 9:00 $\mathrm{h}$ and $12: 00 \mathrm{~h}$, at peak bee activity. The traps were posted in trees within the forest, at its edge and in sugarcane plants inside the plantations, allowing a minimum distance of three meters between them. The baits were monitored simultaneously with one person at each point. Five fragrances that proved to be effective in attracting euglossine males at the study site were used at all points (benzyl acetate, ß-ionone, skatol, eugenol and methyl salicylate). The bees were caught with entomological nets and stored in glasses containing droplets of ethyl acetate and later identified in the laboratory by comparison with the reference collection of the workgroup. The bees were deposited in the Entomological Collection of the Federal University of Pernambuco, Recife. Collection data were entered into a database program.

\section{Data Analysis}

We calculated the Shannon-Wiener index of diversity $\left(\mathrm{H}^{\prime}\right)$ to the base $\log _{2}$ for each sampling point. The Shannon-Wiener indices of diversity were compared using Hutcheson's t-test (ZAR 1996).

The frequency of species and individual abundance between the sampling points was analyzed through G-test for one sample - adherence (ZAR 1996). This test was performed with the software Systat 8.0 (WILKINSON 1998).

We used Jaccard index (KREBS 1989) through NTSYSpc 2.01t software (RoHLF 2000) to evaluate qualitatively the bees' similarity between each sampling point. From the pairwise similarity we generated a single-linkage dendrogram (VALENTIN 2000), where the sampling points were grouped by UPGMA (Unweighted Pair Group Method with Arithmetic mean) method. 

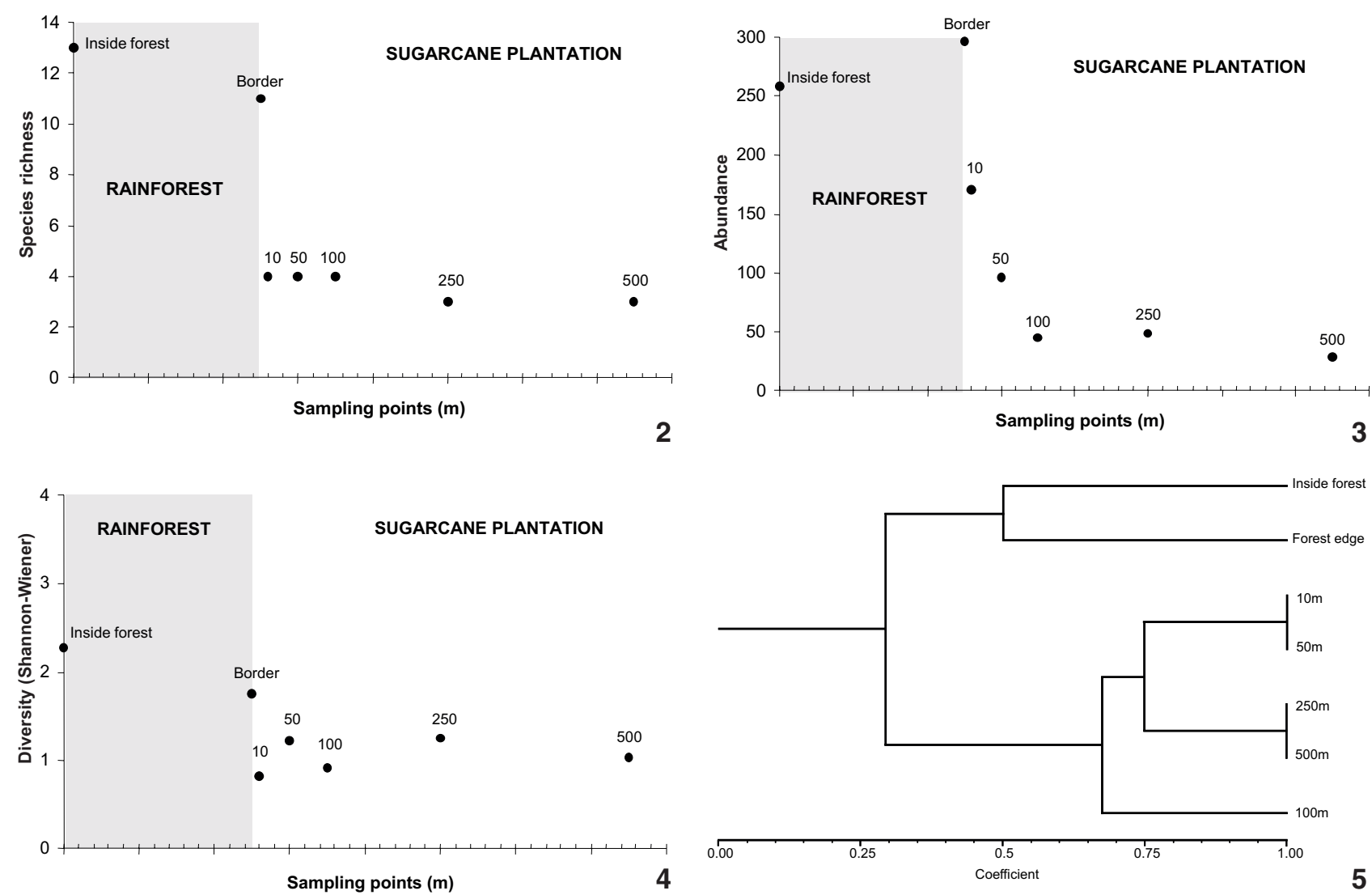

Figures 2-5. Euglossini at seven monitoring points on a transect in "Mata de Bujary", NE, Brazil. The points were on a transect from closed rainforest into sugarcane plantations. The distance between sampling point "forest" and sampling point border was $250 \mathrm{~m}$. (2) Species richness; (3) abundance; (4) diversity (Shannon-Wiener index); (5) Similarity (Jaccard) of Euglossini bees at the different sampling points.

\section{RESULTS}

A total of 945 individuals of Euglossini were recorded: 259 inside the forest, 297 at the edge, 171 at a distance of $10 \mathrm{~m}$ from the edge, 96 at $50 \mathrm{~m}, 45$ at $100 \mathrm{~m}, 49$ at $250 \mathrm{~m}$ and 28 at $500 \mathrm{~m}$ distance. The bees belonged to 16 species: 4 to Eulaema Lepeletier, 1841, 9 to Euglossa Latreille, 1802, 2 to Exaerete Hoffmannsegg, 1817, and 1 to Eufriesea Cockerell, 1908 (Tab. I).

Males of only five euglossine species left the rainforest: Euglossa (Euglossa) cordata Linnaeus, 1758, E. (Euglossa) violaceifrons Rebêlo \& Moure, 1995, Eulaema (Apeulaema) nigrita Lepeletier, 1841, E. (Apeulaema) cingulata Fabricius, 1804 and E. (Eulaema) flavescens Friese, 1899. Only E. cordata, E. nigrita and $E$. cingulata were collected at $250 \mathrm{~m}$ and $500 \mathrm{~m}$ distances from the forest edge. On the other hand, bees like Exaerete frontalis Guérin, 1845, E. smaragdina Guérin, 1845, Eufriesea mussitans Fabricius, 1787, Eulaema (Eulaema) bombiformis Packard, 1869, Euglossa (Euglossella) augaspis Dressler, 1982, E. (Glossurella) crassipunctata Moure, 1968, E. (Euglossa) gaianii Dressler, 1982, E. (Glossura) ignita Smith, 1874, E. (Euglossa) iopyrrha
Dressler, 1982, E. (Euglossella) perpulchra Moure \& Schlindwein, 2002 and E. (Euglossa) securigera Dressler, 1982, were not recorded outside the forest (Tab. I).

Species richness $(\mathrm{G}=15.389$, g.l. $=6, \mathrm{p}=0.0209)$ and abundance $(G=534.95$, g.l $=6, p=0)$ were significantly different between the sampling sites (Figs 2 and 3). The same was true for diversity (Shannon-Wiener index, Fig. 4). The sampling point inside the rainforest showed the highest species richness (13 species) and diversity $\left(\mathrm{H}^{\prime}=2.27\right)$, followed by the point at the edge (11 species and $\left.\mathrm{H}^{\prime}=1.76\right)$. The total diversity of all points together was $\mathrm{H}^{\prime}=2.06$.

The sampling point inside the forest showed a high similarity to the edge point. whereas the sampling points inside the sugarcane plantation were very similar to each other and dissimilar to the forest and edge points (Fig. 5).

The scent which attracted the highest number of individuals was ß-ionone (63.8\%), followed by skatol (22.9\%) and benzyl-acetate (8\%) (Tab. II). Methyl salicylate, eugenol and benzyl-acetate baits showed poor attractivity outside the forest (Tab. II). 
Table I. Species of Euglossini with number of males recorded during simultaneous collection with scent baits at seven sampling points on a transect from closed rainforest into sugarcane plantation to $500 \mathrm{~m}$ distant from the forest edge.

\begin{tabular}{|c|c|c|c|c|c|c|c|}
\hline \multirow{2}{*}{ Species } & \multicolumn{7}{|c|}{ Sampling points } \\
\hline & Forest & Edge & $10 \mathrm{~m}$ & $50 \mathrm{~m}$ & $100 \mathrm{~m}$ & $250 \mathrm{~m}$ & $500 \mathrm{~m}$ \\
\hline Eufriesea mussitans & 1 & 0 & 0 & 0 & 0 & 0 & 0 \\
\hline Euglossa cordata & 121 & 181 & 140 & 64 & 36 & 27 & 20 \\
\hline Euglossa ignita & 8 & 3 & 0 & 0 & 0 & 0 & 0 \\
\hline Euglossa iopyrrha & 3 & 0 & 0 & 0 & 0 & 0 & 0 \\
\hline Euglossa securigera & 0 & 2 & 0 & 0 & 0 & 0 & 0 \\
\hline Euglosa augaspis & 2 & 3 & 0 & 0 & 0 & 0 & 0 \\
\hline Euglossa gaianii & 4 & 1 & 0 & 0 & 0 & 0 & 0 \\
\hline Euglossa crassipunctata & 0 & 1 & 0 & 0 & 0 & 0 & 0 \\
\hline Euglossa violaceifrons & 1 & 6 & 0 & 0 & 1 & 0 & 0 \\
\hline Euglossa perpulchra & 1 & 0 & 0 & 0 & 0 & 0 & 0 \\
\hline Eulaema cingulata & 53 & 50 & 5 & 6 & 1 & 3 & 1 \\
\hline Eulaema bombiformis & 8 & 0 & 0 & 0 & 0 & 0 & 0 \\
\hline Eulaema flavescens & 6 & 6 & 1 & 1 & 0 & 0 & 0 \\
\hline Eulaema nigrita & 47 & 43 & 25 & 25 & 7 & 19 & 7 \\
\hline Exaerete frontalis & 4 & 0 & 0 & 0 & 0 & 0 & 0 \\
\hline Exaerete smaragdina & 0 & 1 & 0 & 0 & 0 & 0 & 0 \\
\hline Total & 259 & 297 & 171 & 96 & 45 & 49 & 28 \\
\hline
\end{tabular}

Table II. Number of individuals of Euglossini collected at the seven sampling points by scent.

\begin{tabular}{|c|c|c|c|c|c|c|c|}
\hline \multirow{2}{*}{ Scent } & \multicolumn{7}{|c|}{ Sampling points } \\
\hline & Forest & Edge & $10 \mathrm{~m}$ & $50 \mathrm{~m}$ & $100 \mathrm{~m}$ & $250 \mathrm{~m}$ & $500 \mathrm{~m}$ \\
\hline Skatol & 60 & 56 & 28 & 30 & 9 & 25 & 8 \\
\hline Methyl salicylate & 23 & 5 & 0 & 0 & 0 & 0 & 0 \\
\hline ß-Ionone & 135 & 185 & 141 & 64 & 36 & 22 & 20 \\
\hline Benzyl-acetate & 30 & 42 & 2 & 1 & 0 & 1 & 0 \\
\hline Eugenol & 11 & 9 & 0 & 1 & 0 & 1 & 0 \\
\hline Total & 259 & 297 & 171 & 96 & 45 & 49 & 28 \\
\hline
\end{tabular}

\section{DISCUSSION}

The baiting experiment shows that the different species of Euglossini have different connections to the forest. To males of 11 out of a total of 16 species, the sugarcane plantation seems to be a barrier to their activity range. These species are closely bound to forest habitats and the males seem to avoid flying over open areas. These species should be more affected by Atlantic Rainforest destruction and fragmentation. Nevertheless, this conclusion has to be treated with care, as some of the forest-restricted species were rare.

In the Brazilian Amazon, Powell \& Powell (1987) showed that the conversion of rainforest to pasture forms barriers to euglossine males. BECKER et al. (1991) suggest that the bees' size is related to the distance between fragments that they can cross. In this context, males of Eulaema bombiformis or E. flavescens should be more capable to leave the forest than smaller bees. The present results show, however, that the different connections of the species of Euglossine to closed forest are not related to body size. Males of the considerably smaller Euglossa cordata occurred in high numbers at the most distant sampling points while no male of Eulaema bombiformis was recorded outside the forest.

Males of species that were frequently recorded at the sampling points in the sugarcane plantation, like Eulaema nigrita, E. cingulata and Euglossa cordata show a high flexibility and capacity of adaptation to disturbed areas. Several studies showed 
that Eulaema nigrita and Euglossa cordata occur in urban environments where they were also found building nests (ZucCHI et al. 1969, Wittmann et al. 2000, Silveira et al. 2002, Darrault et al. 2003). Males of these species should be able to link isolated rainforest fragments.

In other studies related to the flight behavior of euglossine males in fragmented habitats Euglossa cordata, Eulaema nigrita and E. cingulata were also sampled outside forests (RAw 1989, Wittmann et al. 2000). In an experiment of marking and recapture, TonHASCA et al. (2003) showed that these species cross open areas between fragments of Atlantic Rainforest in the state of Rio de Janeiro. Moreover, Euglossa cordata is frequently collected in the region of open Caatinga (succulent thorn-shrub savannah) in Northeastern Brazil (Neves \& Viana 2003).

All studies were performed attracting males with scent baits. Unfortunately, there is only little information on female behavior due to the difficulty of sampling. This would be especially important because the activity range of females is limited by the nest locality. Females make foraging flights and always return to their nest, while males can move by chance in a given region (JANZEN 1971, ACKERMAN et al. 1982).

JANZEN (1971) showed that females of Euplusia surinamensis (Linnaeus, 1758) returned to their nest when released more than $23 \mathrm{~km}$ away. This activity range, however, was determined in an area of continuous rainforest. In regions where forest habitats are restricted to distant fragments, most of the euglossine species seem to stay in the fragments, avoiding open areas. In this condition they consequently may not act as long-distance pollinators.

The reduced or absent flights between forest fragments certainly have a negative effect on the reproductive success of plants that depend on pollination by euglossine bees, especially orchids with perfume flowers. In small forest remnants, the original population of these orchid species is reduced to tiny rest-populations, which may loose their capacity of reproduction. Such a small rest-populations of Gongora quinquenervis (Orchidaceae), for instance, showed no fruit set despite of a $100 \%$ pollinaria removal rate by Euglossa cordata and E. perpulchra in a small forest fragment near the present study site (MARTIN et al. 2003). Species of Catasetum (Orchidaceae) are threatened in the same way, as these dioiceous orchids in the Atlantic Rainforest of Pernambuco are pollinated exclusively by males of Eulaema bombiformis (CARvalHo \& MaCHado 2002), bees that in our study did not leave the closed rainforest.

\section{ACKNOWLEDGEMENTS}

We thank Airton Carvalho, Ana Gabriela D. Bieber, Carlos Eduardo Pinto da Silva, Débora Coelho Moura, Isabela Mariz, Leonardo Pierrot, Martin Duarte de Oliveira, and Reisla Oliveira Darrault, for their help in the field; Márcio Oliveira (INPA) for his help in identification of the bees; Scott Vinson Heald (Cornell University) for revising the english and comments on the manuscript; the Usina Santa Tereza for permission to work in the "Mata de Bujary"; André Santos for his contribution in statistical analysis and providing aerial photos. The study was supported by a grant of UFPE/PIBIC/CNPq to Paulo Milet-Pinheiro.

\section{REFERENCES}

Ackerman, J. D. 1985. Euglossine and their nectar hosts, p. 225233. In: W.G.D'Arcy \& M.D. Correa (Eds). The Botany and Natural History of Panama. St. Louis, Missouri Botanical Gardens, 455p.

Ackerman, J.D.; K.L. Mesler \& A.M. Montalvo. 1982. Food foraging behavior of male Euglossini (Hymenoptera: Apidae) vagabonds or trapliners? Biotropica, Lawrence, 14: 241-248.

Becker, P.; J.S. Moure \& F.J.A. Peralta. 1991. More about euglossine bees in Amazonian forest fragments. Biotropica, Lawrence, 23 (4b): 586-591.

Bezerra, C.P. \& C.F. Martins. 2001. Diversidade de Euglossinae (Hymenoptera, Apidae) em dois fragmentos de Mata Atlântica localizados na região urbana de João Pessoa, Paraíba, Brasil. Revista Brasileira de Zoologia, Curitiba, 18 (3): 823-835.

BuCHMANN, S.L. 1983. Buzz pollination in angiosperms, p. 73114. In: C.E. Jones \& R.J. LitTLE (Eds). Handbook of experimental pollination biology. New York, van Nostrand \& Reinhold, 558p.

Cameron, S.A. 2004. Phylogeny and biology of neotropical orchid bees (Euglossini). Annual Review of Entomology, Palo Alto, 493: 377-404.

Carvalho, R. \& I.C. Machado. 2002. Pollination of Catasetum macrocarpum (Orchidaceae) by Eulaema bombiformis (Euglossini). Lindleyana, Lawrence, 17 (2): 85-90.

Darrault, R.O.; C. Schlindwein \& P. Milet-Pinheiro. 2003. Diferentes demandas ambientais em Eulaema (Apidae, Euglossini) da Mata Atlântica Nordestina, p. 352-355. In: V. CLAudinoSales; I.M. Tonini; E.W.C. Dantas (Eds). Anais VI Congresso de Ecologia do Brasil. Fortaleza, CE-Brasil, XXV+692p.

Dressler, R.L. 1982. Biology of the orchid bees (Euglossini). Annual Review of Ecology and Systematics, Palo Alto, 13: 373-94.

Franceschinelli, E.V.; E.A.B. Almeida; Y. Antonini; B.C. Cabral; R.M. Carmo; A. Damasceno; J.C.R. Fontanelle; V.L.A. Garcia; M.S. Guilherme; R.R. Laps; G.G. Leitão; S.B. Mikich; D.L. Moreira; M.T. Nascimento; A. Nemésio; R. Ribon; F.A. Silveira \& T.H.D.A. VIDIGAL. 2003. Interação entre plantas e animais, p. 275-295. In: D.M. Rambaldi \& D.A.S. Oliveira (Eds). Fragmentação de ecossistemas: causas, efeitos sobre a biodiversidade e recomendações de políticas públicas. Brasília, MMA/SBF, 508p.

JANZEN, D.H. 1971. Euglossine bees as long-distance pollinators of tropical plants. Science, Washington, 171: 203-205.

Krebs, C.J. 1989. Ecological methodology. New York, Harper \& Row, 854p.

Kroodsma, D.E. 1975. Flight distances of male euglossine bees in orchid pollination. Biotropica, Lawrence, 7 (1): 71-72.

Martini, P.; C. Schlindwein \& A. Montenegro. 2003. Pollination flower longevity, and reproductive biology of Gongora

Revista Brasileira de Zoologia 22 (4): 853-858, dezembro 2005 
quinquenervis Ruíz \& Pavón (Orchidaceae) in an Atlantic Forest fragment of Pernambuco, Brazil. Plant Biology, Stuttgart, 5: 495-503.

Moure, J.S. 1967. A check-list of the known euglossine bees (Hymenoptera, Apidae). Atas do Simpósio sobre a Biota Amazônica, Zoologia, Belém, 5: 395-415.

Neves, E.L. \& B.F. Viana. 2003. A fauna de abelhas da subtribo Euglossina (Hymenoptera, Apidae) do Estado da Bahia, Brasil, p. 223-229. In: G.A.R. Melo \& I.A. Santos (Eds). Apoidea Neotropica: Homenagem aos 90 anos de Jesus Santiago Moure. Criciúma, UNESC, XVI+320p.

Powell, A.H. \& G.V.N. Powell. 1987. Population dynamics of male euglossine bees in Amazonian forest fragments. Biotropica, Lawrence, 19 (2): 176-179.

Ranta, P.; T. Blom; J. Niemelä; E. Joensuu \& M. Sittonen. 1998. The fragmented Atlantic Rain Forest of Brazil: size, shape and distribution of forest fragments. Biodivesity and Conservation, Dordrecht, 7: 385-403.

RAw, A. 1989. The dispersal of Euglossine bees between isolated patches of Eastern Brazilian wet forest (Hymenoptera, Apidae). Revista Brasileira de Entomologia, Curitiba, 33 (1): 103-107.

RoHLF, F.J. 2000. NTSYSpc: numerical taxonomy and multivariate data analysis system, ver. 2.01. Exeter Software, Setauket.

Roubik, D.W. 1989. Ecology and natural history of tropical bees. New York, Cambridge University Press, 514p.

RouBIK, D.W. 2001. Up's and down's in pollinator populations: when is there a decline? Conservation Ecology 5 (1): 2. [online] URL: http://www.consecol.org/vol5/issl/art2.

Roubik, D.W. 2004. Long-term studies of solitary bees: what the orchid bees are telling us, p. 97-103. In: B.M. Freitas \& J.O.P. Pereira (Eds). Solitary bees. Conservation, rearing and management for pollination. Fortaleza, Universidade Federal do Ceará, Imprensa Universitária, 285p.

Roubik, D.W. \& J.D. AcKerman, 1987. Long-term ecology of euglossine orchid-bees (Apidae: Euglossini) in Panama. Oecologia, Berlin, 13: 321-332.

SchlindweIn, C. 2000. A importância de abelhas especializadas na polinização de plantas nativas e conservação do meio ambiente. In: Anais do IV Encontro sobre Abelhas, Ribeirão Preto, p. 131-141.

Received in 18.III.2005; accepted in 27.IX.2005.
Silveira, F.A.; G.A.R. Melo \& E.A.B. AlmeidA. 2002. Abelhas Brasileiras: Sistemática e identificação. Belo Horizonte, F.A. Silveira, 253p.

Tonhasca, A.; G.S. Albuquerque \& J.L. Blackmer. 2003. Dispersal of euglossine bees between fragments of the Brazilian Atlantic Forest. Journal of Tropical Ecology, Cambridge, 19: 99-102.

VALENTIN, J.L. 2000. Ecologia numérica: uma introdução à análise multivariada de dados ecológicos. Rio de Janeiro, Interciência, $117 \mathrm{p}$.

Vogel, S. 1962. Duftdrüsen im Dienste der Bestäubung. Über Bau und Funktion der Osmophoren. Akademie der Wissenschaften und der Literatur, Abhandlungen der mathematisch-naturwissenschaftlichen Klasse, Stuttgart, 10: $1-165$.

Vogel, S. 1966. Pafümsammelnde Bienen als Bestäuber von Orchidaceen und Gloxina. Österreichische Botanische Zeitschrift, Viena, 113: 302-361.

Vogel, S. 1999. Von Ölblumen und Parfümblumen, p. 74-87. In: G. Zizka \& S. SChenckenburger (Eds). Blütenökologie, faszinierendes Miteinander von Pflanzen und Tieren, Kleine Senckenberg-Reihe 33, Palmengarten Sonderheft 31. Frankfurt, Waldemar Kramer, 173p.

WILKINSON, L. 1998. SYSTAT. ver 8.0. SPSS. Chicago.

Wittmann, D.; M. Hoffmann \& E. Scholz. 1988. Southern distributional limits of euglossine bees in Brazil linked to habitats of the Atlantic- and Subtropical Rainforest (Hymenoptera: Apidae: Euglossini). Entomologia Generalis, Stuttgart, 14 (1): 53-60.

Wittmann, D.; A. Hamm; I.C. Machado; D. Schiffler \& C. Schlindwein. 2000. Artenvielfalt von Euglossinen in einem Regenwald-Fragment und angrenzenden landwirtschaftlichen Nutzflächen in Pernambuco, Brasilien, p.67-70. In: T. Osten (Ed.). Beiträge der Hymenopterologen-Tagung in Stuttgart 2000. 73p.

ZAR, J.H. 1996. Biostatistical analysis. New Jersey, PrenticeHall, 663p.

Zucchi, R.; S.F. SAKagami \& J.M.F. Camargo. 1969. Biological observations on a Neotropical parasocial bee, Eulaema nigrita, with a review on the biology of Euglossinae (Hymenoptera, Apidae). A comparative study. Journal of the Faculty of Science, Hokkaido University (VI, Zoology), 17: 271-380. 